\title{
Banking on the Underworld. A Strictly Economic Appreciation of the Chinese Practice of Burning (Token) Money
}

Guido Giacomo Preparata

ABSTRACT

The custom of burning mock-money as a symbolic offering of nutrients and sustenance to one's ancestors in the Afterlife is here analysed in terms of its economic meaning and significance. The theme is treated from two different angles. One is that of the political economy of the gift, which concerns itself with the final uses to which society conveys its economic surplus. The other is that of monetary institutionalism, which seeks to understand what the practice itself actually represents in light of the monetary arrangements that rule the economic exchange within the community itself. The thesis is that, at a first remove, the custom appears to fall into the category of "wasteful expenditure," in that it is not manifestly conducive to any augmentation of the system's efficiency. But on a subtler level, it is not precisely so for two orders of reasons. First, because the custom is habitually accompanied by subsidiary donations; second, because, in this donative moment, the custom importantly reveals, through its conversion of real cash into "sacrificial" token-money, a constitutive yet hidden, property of money, namely its perishability.

Keywords: Ghost-money; money; token-money; symbol; liturgy; ancestor cult; demurrage; gift; China; Taiwan; afterlife; superstition; religion; anthropology; sumptuary expenditure

For citation: Preparata Guido G. Banking on the Underworld. A Strictly Economic Appreciation of the Chinese Practice of Burning (Token) Money. Review of Business and Economics Studies. 2021;9(4):32-45. doi: 10.26794/2308-944X-2021-9-4-32-45

ОРИГИНАЛЬНАЯ СТАТЬЯ

\section{Банковское дело в преисподней. Исключительно экономическая оценка китайской практики сжигания денег}

Гвидо Джакомо Препарата

\begin{abstract}
АННОТАЦИЯ
Статья посвящена анализу распространенных на Дальним Востоке (Индия, Китай) обычаев сжигания или закапывания артифициальных (хотя не только) денег. Целью статьи является выявление экономического значения и значимости таких действий как символического подношения питательных веществ и пропитания своим предкам в загробной жизни. Проведен анализ с двух разных сторон с применением метода сравнительного анализа. Одна сторона - политическая экономия обилия, где общество передает свой экономический излишек на реализацию конечных целей. Другая - это монетарный институционализм, который ставит вопрос: что на самом деле представляет собой сама практика сжигания в свете денежных механизмов, которые управляют экономическим обменом? Тезис этой статьи состоит в том, что на первый взгляд кажется, что обычай попадает в категорию «расточительных расходов». Однако анализ показал, что это не совсем так. Автор сделал выводы, что, во-первых, такой обычай, как правило, сопровождается дополнительными пожертвованиями; и во-вторых, обычай, превращая реальные деньги в «жертвенные» символические (токен) деньги, существенно раскрывает конститутивное, но скрытое свойство денег, а именно их тленность.

Ключевые слова: призрачные деньги; деньги; разменные деньги; символ; литургия; культ предков; демерредж; подарок; Китай; Тайвань; загробная жизнь; суеверие; религия; антропология; роскошные расходы
\end{abstract}

Для цитирования: Препарата Г.Д. Банковское дело в преисподней. Исключительно экономическая оценка китайской практики сжигания денег. Review of Business and Economics Studies. 2021;9(4):32-45. doi: 10.26794/2308-944X-2021-9-4-32-45

(c) Guido Giacomo Preparata, 2021 
One of my Quanzhou interviewees pulled out several leaves of the Taiwan top-of-the-line Triad Gold from a chest of drawers as if she was storing some great heirloom; the way she handled it, I could scarcely imagine her burning it, although burning it is the proper way of storing its value.

C. Fred Blake, Burning Money ${ }^{1}$

\section{Introduction}

The Chinese custom of burning paper tokenmoney has occasioned a most interesting production of anthropological research. This corpus has shed penetrating light on a central aspect of ritual practice, which is the relationship that various cultural groups - in this instance, the Chinese - entertain with the Afterworld, and of their ways of giving expression to this peculiar form of "transaction," of "traffic" with the supernatural "space," and the (supersensible) realm of the dead, in particular.

The custom has been amply dissected along the lines of cultural, religious, ethnographic, archaeological, and, of course, Sinological inquiry. For the purposes of this article, I will tap this patrimony of scholarly information in order to lay out the basic phenomenology of the custom, which I intend to discuss and analyse from a strictly economic vantage point, i.e., from the exclusive viewpoint of monetary economics and political economy.

There might be substantial merit in doing so since, to date, there appears to have been no systematic economic gloss of Chinese "burning money"-the latter is, ostensibly, a monetary practice, after all - and the little done in this department thus far, by anthropologists themselves, is rather in the nature of an afterthought, which relies, for lack of more "up-to-date and specialised tools," on Marx's basic aperçus on money. Aperçus which are, despite their "classic" status, truly, not just merely passé, but conspicuously unequal to the complexity and vastness of the monetary phenomenon and its associated debate on how to manage and/ or reform it.

The ramifications of such a debate - also, and most conspicuously in China herself these days have presently reached significant levels of technical and institutional sophistication, especially in light of the various diatribes on the nature of money that have been simmering for the past

\footnotetext{
${ }^{1}$ Blake, 2011, p. 44, emphasis added.
}

twenty years and, more importantly, in light of the ongoing re-reorganisation of the International Financial System itself after the crash of September 2008, lately within the cybernetic arena where "digital cash" and "cryptocurrencies" are allegedly fighting it out.

Although reference to these late developments will be merely hinted at in the final segment of this piece (they are tangential to the subject at hand), their mention is nonetheless relevant in that it contextualises and frames the whole discussion of this exquisitely anthropological topic in terms of the specific conceptual categories that will be used in this essay. These are 1) "the political economy of the gift" (an approach based on the foundational analysis of Thorstein Veblen, and a subsidiary advertence to Georges Bataille), (see, Preparata, 2008) which is known to anthropologists; and, thoroughly unbeknownst to mainstream social scientists, 2) the notion of the "perishability" of money (viz. Silvio Gesell's Theory of Interest, and its "theosophical" variant: Rudolf Steiner's "Ages of Money"), which, most intriguingly, is now holding centre stage in the propagandistic stage of monetary forecasts animated by the spokespersons of central banking (Rogoff, 2016, pp. 5-6, 158-167).

In sum, the article's thesis starts by acknowledging that the Chinese practice of burning paper money is, indeed, as anthropologists have noted, a very mildly dissipative, "sumptuary" form of (liturgical) activity. Economically speaking, the practice remains "sterile" so long as it is an end unto itself; in other words, so long as it occasions no other beneficial economic effect past the burning of the paper-tokens (along with incense, food offertories and other oblations). Thus, as sumptuary dissipation, the custom may be critically characterised as a "superstition" that merely feeds a private industry of no "life-furthering substance," so to speak. The practice, however, comes into more virtuous focus if, on the other hand, it occasions charitable gifting, as it customarily does in all those instances - which appear to be the majority - in which the token-money is burned in concomitance with real cash offering to the temples where the "sacrifice" takes place.

Above and beyond this aspect of the custom, the "conversion" of cash into token-money destined to be burned - a conversion which is effected through a purchase - hides a fundamental trait of the nature of money. And that is the fact that 
even though we do not see it - or rather, even though we have not been "institutionally allowed" to see it - there is an age behind/"inside" every bill. Herein, indeed, lies the gist of the crucial notion of "monetary perishability." The "age" is not the life-cycle of the paper scrip itself, but, in economic principle, that of the goods the bill is supposed to shepherd when it circulates and is being exchanged. The point here is that all money offered in a donative fashion is de facto money approaching death. And what the custom of burning token-paper does with this fundamental economic reality, which is no "illusion" at all, is to make it manifest - not just symbolically, but, much more interestingly, ritually so.

The essay is divided into three parts. A brief exposition of the anthropological narratives of the custom of burning token-money - with a special emphasis on C. Fred Blake's recent book Burning Money - is followed by a summary of the prevailing cultural and Marxian interpretations of the phenomenon. The discussion proper consists of three sections: the first, titled "Devout Observances," assesses the burning of token-money in the key of Veblen's discriminative analysis of what constitutes life-enhancing versus "conspicuously wasteful" production. The second subsumes the custom as a special and revealing illustration of the ways in which the monetary circuit is irrepressibly bound to give vent, despite the abuses and distortions of human arrangements, to the inherent tendencies of its foundational make-up. What it "vents out" is the fact that because economic items have a life-cycle, so does money, and, consequently, that the death of money is, without fail, consummated with a "gifting" rite of passage, so to speak. The rite of paper-torching is one such (cultural and ostensibly liturgical) instance. Brief reflections on the economic virtuousness of the custom gauged in terms of its charitable effects and a tangential forecast on the custom's survival prospects in the new century concludes the piece.

\section{The Anthropological Facts of "Burning (Token-) Money," in Extreme Synthesis}

Elites celebrate their power also by paying ritual homage to their line of ancestors, i.e., to their sovereign bloodline, which is construed as a manifest expression of their Heaven-mandated superiority vis-à-vis the rest of the population. China's imperial leaders and wealthy absentees have been burning token-money for at least a thousand years (allegedly, since the era of the Han dynasty, 206 BCE- 220 CE), as a way of propitiating the spirits of the Afterworld and of providing their ancestors with "wealth," with "spiritual sustenance" on the Other Side." In line with the emulative dynamics of feudal hierarchies, the lesser strata of society have keenly taken to imitating the custom, thus acquiring the confidence that they, too, just as importantly, had a "line" of dear (dead) ones to nurture (liturgically), as well as demonic forces to pacify. As the old credence held that all living souls, upon passing, returned to their aboriginal status of "ghosts" (gui), the mock-money incinerated for their sake was accordingly named "ghost-money." So, the lower castes, too, have been busily and ceremoniously engaged in burning ghost-bills ever since. By burning objects of all kinds - or paper-notes bearing effigies of those objects-, it is believed that one may "send," "transmit" them to the Underworld. Initially, real cash was buried with the dead. Out of a concern that doing so would have deflationary effects (i.e., a withdrawal of purchasing power from the economy)-a concern which, interestingly, as we shall see, would reappear in connection with the burning of mock-paper - it was after that thought more fitting to inter the dead with "spirit money," instead, i.e., with clay replicas of gold coins. The provision of spirit money was also dictated by the additional "exigency," for the departing soul's ultimate comfort, to bribe the administrators in the world of the dead (Seidel, 1982). As to the practice to incinerate objects, it is traced back to credence, which is found both in Zoroastrianism and Hinduism, that fiery combustion is an effective means of shipment to the Other Side.

Anthropological accounts generally refer to such burning-paper as "paper-money," for that is what it is made of, in order to distinguish it from realmoney, i.e., currency, which, it, too, may be paper, i.e., "cash." Because cash/currency is indeed for the most part paper-money, in order to avoid confusion, I prefer to designate these flammable bills as "token-money," which is to say that they are not so many replicas as they are surrogates, symbolic effigies of cash; and by cash I mean, conventionally, the actual purchase money that circulates in the economy. 
As dictated by the custom, token-monies burnt for the sake of divine propitiation ("offerings to the gods") take the form of symbolic "gold money." In contrast, token-monies burnt for ancestors, ghosts, and manes are "silver-money": i.e., paper bills covered with thin films of gold and silver tinfoil, respectively. The division between the ones and the others is not absolute, though, considering that certain supernatural entities may be eventually offered "paper-gold" as they happen to shed or lose their sinister valence in the course of their tortuous hagiological vicissitudes - as when they are felicitously promoted from "demons" to "saints." Other sources specify a more rigid, standard tri-partition of the recipients of "spirit money" (gun-cua): goldpaper for the gods, silver-paper for the ancestors, but only handouts (kieng-i) for the ghosts. Typically, "ghosts" are somebody else's "ancestors."

A mercantile eschatology appears to be underpinning this particular practice. In other words, the credence here is that in order to be born, one must become indebted to a Treasury of the Underworld; one must, therefore, take out a loan with a Bank of the Netherworld (Mingguo yinhang), or with what may be thought as a branch of the "Hell Bank." The balances thus acquired through this "mystical debt" enable the borrowing soul to purchase a body, certain longevity, a social status, clothes, and food, the detailed invoicing of which are meticulously recorded by the accounting department of the infernal bank. When the balances have been entirely spent, there comes death. It is then up to the deceased person's sons and daughters to settle the debt with a special funerary ritual during a ceremony entitled "Reimbursement of the Debt"; they have 49 days after the "departure" to do so. There were, in addition to this idea, creedal practices of a horoscopic nature, whereby one's longevity and emoluments (pecuniary bounties) throughout one's life-time could be respectively and variously increased, depending on one's birthdate, by offerings of rice and silk.

Furthermore, the life-allotment purchased before being born is menaced throughout one's existence either by illness or by a surfeit of fortunateness. Maladies may be the result of an error, a sin, a misdeed, which curtails one's life- reserve; "surfeits of fortunateness," instead, are bountiful, yet excessive events, such as an extraordinary bumper harvest or an extravagantly fastuous wedding. They, too, by their blinding effulgence, which disrupts the harmonious pace of the MidPath, end up parching the reserve of life-fuel one originally acquires before coming to earthly life. Both instances demand redress; there is for this purpose - that of "Restoring Destiny"- special money to be burnt which, depending on the type of event (excess or malady), may be respectively addressed to the Celestial Jurisdiction or the Infernal Administration (Hou, 1971).

One immediate inference that emerges from the foregoing is that the Chinese supernatural through the eyes of the peasants is "a detailed image of Chinese officialdom."

Judged in terms of its administrative arrangements, the Chinese imperial government looks impotent. Assessed in terms of its long-range impact on the people, it appears to have been one of the most potent governments ever known, for it created a religion in its own image. Its firm grip on the popular imagination may be one reason the imperial government survived so long despite its many failings. Perhaps it is also the reason China's revolutionaries have so often organised their movements in terms of the concepts and symbols of such foreign faiths as Buddhism and Christianity. The native gods were so much a part of the establishment that they could be turned against it (Wolf, 1974, pp. 145, 179-181).

Though the Buddhist imagination inspired his conception of the underworld, the Chinese peasant construed Hell as a "multi-layered Yamen [administrative district] staffed with supernatural bureaucrats." In this sense, most of the "spirit money" that is channelled, via incineration, to the Bank of Hell at the end of a funeral is only partly earmarked for post-mortem "sustenance": a substantial portion thereof, as said, is actually laid in as baksheesh for surviving the day-to-day routine in the strictures of Inferno's Structure; i.e. for bribing "officials, who might otherwise subject the deceased to his merited punishment and perhaps some unmerited punishment as well."

The different categories of "spirit money" are said, "to reflect the divisions of the supernatural world into spirits modelled on senior kinsmen [silver effigies], strangers [handouts], and imperial bureaucrats [gold effigies]." Uses and interpretations of such token offerings are also said to vary considerably. According to one particular "expert" testimony reported in one study, token-money torched on behalf of the gods "is not money at all," 
for the gods, in this person's view, have clearly no need of money whatsoever, but is rather like something in the nature of a petition which (hapless) people customarily make when, suppliantly, they seek redress, compensation, justice, goodwill, benevolence - from on high, in this world as in the next.

And just as the devout money-burner cannot brook the thought that an infernal bureaucrat might bully his genitor in the Afterlife, and, therefore, that this apparatchik from hell must be "greased," the devout money-burner is likewise wary of being cursed by a beggar whose entreaties he ignored. The curse may afflict him in the form of a malady or of damage to his property. Like bandits (low-tenacity, yet death-prone barbarous types) and ghosts, beggars are feared, and as beggars, bandits, and ghosts (the latter being the spirits of strangers/outsiders, of other people's ancestors, and as such, unpredictably dangerous) are "socially despised."

The social identities of the three are so similar that bandits and beggars are sometimes treated like ghosts.

Once in Northern Taiwan, there had been an established ritual to deflect the evil - or rather, the "unpredictably dangerous - eye of the ghosts during the seventh lunar month. According to an account of the late nineteenth century, tradition imposed that a lush banquet be ostensibly arranged within the sacred confines of the celebratory venue and "offered up to all the wandering spirits who had answered the summons of the gongs. [After] the ghosts had time to satisfy themselves," the "remains" of the feast were turned over to "a very unspiritual mob of thousands and thousands of hungry beggars, blacklegs, desperados of all sorts," (Ibidem, pp. 171-174) who had gathered from the country towns and city slums at the offertory's venue, lying in wait for what must have unfolded like a feral consummation of liturgical victuals.

\section{The Custom Today: Beliefs \& Prospects}

The custom today continues. It is alive and well. The amount of wealth that goes up in ashes as a result of this Chinese "potlatch for the spirits" remains formidable. Yet, it is nonetheless the case that the ritual consummation tends to be concentrated on specific holidays since the younger, more resource-conscientious generations have overall scaled-down the torching out of strictly environmental worries. Indeed, to the question posed a year or so ago by devotees whether it was acceptable to pray for one's dead without having to burn token-money, the Daoist priesthood of Xiangtian Temple in Taipei responded positively by way of oracular communication.

On the occasion of culminating festivities, such as Tomb-Sweeping Day, hundreds of tons of paper are burnt, along with incense. This token-money complex-"I burn [objects in effigy], therefore I am"-continues to animate what has been seen as a "show of extravagance." Unsurprisingly, in hyper-modern times such as ours, many, within China herself, stigmatise the practice as splurging "nonsense," "foolishness," and superstition. A portion of the newer, more sceptical generations intensifies the scorn by berating the custom as "perversity and deceit." By which is intended the delusion entertained by the devout that he may more or less cunningly manage his relations with the dead as (e.g., by conjuring excuses and pretexts in order to burn only when, and how, it suits him), as much as the airs of holier-than-thou selfrighteousness that he devout puts out vis-à-vis his social milieu) (Blake, 2011b).

In his authoritative Burning Money, C. Fred Blake affirms that, to his knowledge, no culture substitutes paper (token-money) for (real/fiat) money in ritual offerings to the extent that Chinese culture does. To this day, Taiwan is said to possess "the most impressive array" of token-monies. Interestingly, such burning-money continues to function as "tollway money" not just to propitiate the transition of the departing soul from our realm to the other, but also "to protect the souls passing into this world as children." And that is because, as they seek embodiment, the souls coming to this world are more vulnerable. With suggestive imagery, it is said that "from inside the womb until adolescence, the souls of youngsters may be considered as residing in a kind of uterine limbo or flower garden."

While parents nurture the physical bodies of their children, the flower spirits watches over and helps the corresponding soul to pass obstacles on its way to adulthood (Blake, 2011a, pp. 2, 9, 12, 15, $36,33,34)$.

Like yesterday, the devout crowd honours the supernatural realm by burning its token-money according to different levels of expensiveness, which reflect the ranks of the ghostly recipients (again, in descending order: "gold-paper," "silver- 
paper," and lesser paper-bills). Hand-made, i.e., "artisanal" token-paper is especially favoured on account of its being "more genuine, more effective"; that is to say, on account of its less or antiindustrial character - something which is, indeed, "required" for crafting objects meant to afford a "sacred connection." This proviso appears to be intimating that the "titanic forces" of industrial throughput ought to be "insulated," i.e., removed from the manufacture of such symbolic conductors. It is the search for that "human touch," for the mark of labour-intensive supererogation, the mark of "conspicuous wastefulness" (in producing the token-money) that appears to guarantee, to preserve the (traditionalist) purity of the exchange via the incineration.

In any event, the cash the devout spend, or rather convert into token-money is not, monetarily speaking, the pecuniary affair of a temple, i.e., of a religious body, though some temples may have a commercial stake in stores selling token-money. The stake is generally an informal one - a donative understanding of sorts - considering that religious organisations would otherwise be taxed. All of which is to re-affirm that the practice of burning token-money feeds a substantial industry made-up of "countless workshops," ranging from individual family operations to large-scale industrial businesses that, in some instances, occupy entire villages.

Given modern scepticism and the ongoing, swift, and often disfiguring transformation of Chinese society, anthropologists wonder how a custom such as token-burning, which is qualified as the expression of "small agrarian producers living in a feudal society," might survive, adapt, or change in the face of globalism. In other words, they ask themselves how that ancient "hierarchy of spirits based on sumptuary privilege," for whose sake the token-money is burned, is going to weather the spiritual change of the guard as a consequence of China's life-changing induction into the World Trade Organization in 2001 (through American and British sponsorship).

This is a question that also pertains to the very perception the devout token-burners entertain of the custom itself. It appears that on a cultural level, they are all perfectly conscious of the, let us say, "jocose" nature of the practice: a founding myth thereof recounts that the ritual act of burning money (shaozi) for resuscitating, or aiding the dead, was originally born as a "ruse," i.e., as the con of some trickster (in the story, a small businessman seeking to unload in some fashion coarse paper nobody wanted)-much as the banker's "ruse" of the fractional reserve - which, nevertheless, seems to have touched a raw nerve in society's collective imagination. The founding tale struck its root in society's congenital need to keep a (ritual) connection with the overawing realm of death, of loss, of lost love.

In this bearing, although Confucian administrators understandably criticised the custom as a sterile dissipation of wealth and labour-power for the (symbolic) sake of foreign deities (Buddhism's) that was of no direct benefit to State revenues, they could not, on the other hand, fail to acknowledge its cohesive virtue in that it aligned the interests of the lower strata with those of the "genteel and credentialed" classes. We began our exposition precisely with this observation.

[Token-]money burning was a vulgarisation of the sumptuary privilege that gave the ruling ranks their appearance of privilege and power (Ibidem, pp. 37, 46, 51, 58-62, 68, 69, 73, 74).

Some elite philosophers clearly saw merit in this "alignment" and decreed thereby that the practice was indeed not vulgar, as they themselves were seen burning mulberry-bark paper-money -i.e., the very paper-notes which monetary historians eulogise as the fruit of the first sophisticated regime of fiat money - Genghis Khan's - and which Ezra Pound himself, in his invective furibonda against (the bankers') Usura (Pound, 1996), sang as one of the celestial archetypes of wholesome money (Pound, 1978, pp. 100-101).

Blake construes this "vulgarisation" as the factual celebration of a sacrifice of sorts (a "holocaust"), which is to say, that via the burning of token-money, China's lower classes have been "mystifying [their] exploitation by dramatising it in plain view": i.e. they have been sublimating their exploited status by staging the cultural drama of the bonfire of (preferably hand-made) moneyreplicas (lengthily and tediously folded by hand), along with that of, e.g., foot-binding - these two being coupled in the analysis as germane forms of mutilation, monetary the one, corporeal the other (Blake, 2011a, pp. 108, 133, 138, 141).

As said, and as is to be expected in the sweep of devout shuffle, the burning of mock-money has also been historically accompanied by the 
invocation of Buddhist divinities (to the chagrin of Buddhism's orthodox sages) (Yen, 2007, pp. 74-75), much like devout Catholics court their myriad saints and remember their dead by lighting ceri and commissioning messe cantate (tallow candles - fire, again - and sung masses). "Burn paper and praise Buddha." Nowadays, instead - to come to the issue of the bonfires' otherworldly recipients - the saintly hierarchies have somewhat changed complexion, or, in the best of circumstances, it has been the case that yesteryear's grandees of Hell have made room for their Communist epigones: in a single blaze, one may burn notes bearing the effigy of Mao along with that of the Jade Emperor. Moreover, since the 1950s, the market for token-money has been overrun with a plethora of so-called "ghost bills," of "Hell Bank Notes." These bills, which are explicit, Globalisation-driven simulations of national currencies, especially western ones (of the dollar above all, for obvious reasons), appear to be "destined for the less exalted spirits, deceased members of the family, old friends, [and] more or less anonymous ghostly figures." By "contagious magic," as it were, a ghost bill acquires "value" by being pressed against the real-note it was made to mimic: by rubbing against it, it putatively acquires its "numinosity." This new profusion of bills comes with new sets of token representations: one may presently convey to the Otherworld appliances, automobiles, jet planes, steamships, touristic airfare to America, and even concubines, Viagra pills, and condoms for despondent, forlorn ancestors who might periodically suffer from bouts of maudlin boredom.

Speaking, then, of pecuniary numinosity, the question most frequently asked is: Why not burn real money? Why not just torch the cash equivalent of the intended donation? Why go through this entire, elaborate, wasteful (considering that a real, low-denomination bill buys wads galore of token-money), and polluting procedure? In certain cases, though they tend to be infrequent - as exceptions to the rule-, this has been done and is being done, oftentimes profusely. Indeed, the devotional sub-system of money-burning does not appear to have deprived itself of a certain amount of ambivalence in this respect. Inadvertently tapping into deeper currents of humour and speaking of sex, one store-owner suggested that one had better burn the condom itself since it cost less than the paper it could be printed on (Blake, 2011a, pp. $145,158,167,178,182)$.

For Blake, "the popularisation of [token-]money facsimiles of real currencies is a direct reflection of the commoditisation process"; the custom is said to be "more than a ritual practice" in that it not only affords insights into the creedal space of the devotees, and into the ways in which this space is shaped by its underlying economic template, but in that it also reveals something of the dynamics of credence itself in "modern times," which are perceived by many as "unauthentic" and "synthetic," as "unreal." The popularisation of [token-]money simulacra (Blake, 2011b, pp. 459, 460, 461, 466) supposedly reveals the symptoms of modernity's syndrome; a syndrome which has arisen as a consequence of the "destruction of reality" and tradition wrought by the pervasive mechanisation of modernity. Such a syndrome, when it rages, causes people to lose, to wrap themselves in imitations, which they mistake for "the real," which, in turn, is said to exist no more. ${ }^{2}$

The anthropological analysis seems to suggest that we are presently undergoing a transition, in which the more ancient practices and being slowly shaped and altered by modern, consumeristic stylemes, on the one hand, and by the pressure of dollar-fueled hegemony of Anglo-American Globalism, on the other. Therefore, one has yet to observe how this practice will evolve considering above all that China's cultural identity and the eventual capability of affirming what is truly hers (whatever that is or may be, in the future)-that is, past and beyond this initial stage of mere labour- $/$ capital-intensive mimicry of western models - is at this juncture still a work-in-progress, i.e., something in fieri of no foreseeable shape.

\section{Devout Observances}

From a strictly economic vantage point, a custom such as that of burning ghost-bills with a view to dispatching equipment to the departed and wherewithal wherewith to bribe infernal officialdom is easily identifiable as a devout observance such as it typically arises in anthropomorphic cults. In what ought to be a social scientist's first compass, The Theory of the Leisure Class (1899),

${ }^{2}$ For a discussion of the influence of Bataille's sociological insight on Baudrillard's work see Preparata (2011, pp. 198-206). 
Thorstein Veblen posits the analytical framework of such phenomena in these terms:

The anthropomorphic cults have come down from that stage of industrial development and have been shaped by the same scheme of economic differentiation - a differentiation into consumer and producer - and they are pervaded by the same dominant principle of mastery and subservience [...]. The anthropomorphic divinity is conceived to be punctilious in all questions of precedence and is prone to an assertion of mastery and an arbitrary exercise of power - an habitual resort to force as the final arbiter (Veblen, 1899, pp. 301-302).

In such a creedal space, modelled, as we have seen, after the bureaucratic structures of the empire, a bribe in the real world translates into "propitiation" in the Hereafter. "The act of propitiation or of worship," continues Veblen, "is designed to appeal to a sense of status imputed to the inscrutable power that is thus approached. The propitiatory formulas most in vogue are still such as carry or imply an invidious comparison. A loyal attachment to the person of an anthropomorphic divinity endowed with such an archaic human nature implies the like archaic propensities in the devotee" (Ibidem, p. 302). This, then, might be said to account for the shared liturgical space between the wealthy and the indigent: the latter express their emulative fealty to the former not only by imitating the propitiatory practices of their higher-ups (in the "invidious" pursuit of higher status), but also by personalising the ceremonial, as it were, with the provision of an extra stash of hush-money, as if to bring thereby in further relief the tacit reality of their immutably subservient status.

Economically, the devout frame of mind calls for the devout consumption of goods and services. "The consumption of ceremonial paraphernalia required by any cult, in the way of shrines, temples, churches, vestments, sacrifices, sacraments, holiday attire, etc.," argues Veblen, "serves no immediate material end." It leads him to infer that "all these material apparatus may, therefore, without implying deprecation, be broadly characterised as items of conspicuous waste" (Ibidem, pp. 306-307, emphasis added). The theoretical inclusion of burning netherworld bills in the category of "conspicuous waste" appears to be all the more justified by the additional clue that, in the "devotional business" of communicating with the other side, (stannous) paper "tediously" and lengthily" folded "by hand," and/or all "hand-made" token-money is more highly prized than similarly-looking yet industrially confected items. This fact re-joins Veblen's observation that between two objects of outwardly identical appearance and serviceability, the "requirement of conspicuous wastefulness"-which is typically denoted by the supererogation of several more hours of manual labour for the making of the one than for the other - leads the devout mindset to find superior gratification in the article bearing higher "honorific" (i.e., wasteful) value (Ibidem, pp. 127-128).

Fixated as Veblen was on emphasising how the "Machine Process most assuredly warranted the material efficiency of the community" (Veblen, 1904), which he himself "devoutly" hypostatised as the foundation of his Utopia of the Engineers' Councils (Veblen, 1921), he could not but chastise "devout observances"-despite his repeated protestations that the moral and aesthetic qualities of devotional activity were not part of his strictly economic analysis - as obstructions "to the most effective organisation of industry under modern circumstances." In this regard, he saw "the sentiment of personal fealty, and the general habit of mind of which that sentiment is an expression, [as] survivals which cumber the ground and hinder an adequate adjustment of human institutions to the existing situation" (Veblen, 1899, pp. 304, 307). And such appears to be, to a certain extent, the prejudicial grounds from which China's newer waves of doubting publicists launch their "lampooning" invectives against the custom of burning token-money. It is also the case, on the other hand, that Veblen's economistic censure, overlaps, in a way, with the early dirigiste qualms expressed by the Confucian administrators as to the strictly material effects of the custom on the overall cycle of the System's political economy.

Likewise, in the case of ghost-worship, or rather, of "ghost-bribing": the fact that ghosts, though cared for by others, are considered "potentially dangerous because they are strangers or outsiders" (Wolf, 1974, p. 172, emphasis added), could also be chalked up to the same atavistic mindset, to the same "spiritual attitude or habit of mind" which results from the [consuetudinary] contemplation of the anthropomorphism, clannishness, and leisurely self-complacency of the gentleman of an early day" (Veblen, 1899, pp. 391-392, emphasis added). Being ad-perceived, through a tribal lens, 
not as "one of ours," and thus, as potentially hostile, ghosts perforce need to be pacified.

But, in canvassing the custom of paper-burning, Veblen's theory can only be stretched thus far; and that is because the devout, though intrinsically harmless practice of incinerating token-money (aside from its polluting "externalities"), beyond evoking bland forms of clannishness along with reminiscences of a meek subjection to the aldermanic intrusion and malversation of imperial officials, bears, ipso facto, none of those truculent marks of barbarous domination, prepotence, and dissipative effusion that are more idiosyncratically characteristic of the West's "demented" attraction to power (Tarde, 2015, p. 20). This is understood, and the limits of this interpretative approach are even more manifest when the custom is stacked against the bloody and savagely violent outlets (viz. holocausts, sanguinary emulative rituals, war \& rearmament, sacrifice, squander, etc.) to which the economic surplus is, as Georges Bataille incisively contended -le trop-plein-, methodically, systematically, and ritually conveyed - as an "accursed share" (Bataille, 1967). Bonfires of token-money do not really possess that disquieting awesomeness that characterises all sacrificial forms, even symbolic ones.

In this sense, from a strictly economic viewpoint, one may question whether it is apposite to liken money-torching to a "holocaust" and thereupon to assimilate the latter with foot-binding. Footbinding, like Veblen, again, observed in the famous chapter on the "Canons of Pecuniary Taste" of his magnum opus, appears, in fact, to be a contradistinguishing expression of the "barbarous status of a woman." Which is to say that, in order to signal her costly, trophy-like thralldom - as sexual capital- to the estate of the lord, the mistress of the palace is conventionally subjected to a vestimentary etiquette that is so designed as to suggest her thorough incapability of "useful effort," and thereby, her helplessness in the face of the practical obstacles of procuring one's livelihood. She is thus garb-wise and corporally "fashioned" according to varying aesthetic solutions betokening, more or less perversely, her "need" to be "supported in idleness by her owner."

[Woman] is useless and expensive, and she is consequently valuable as evidence of pecuniary strength. It results that at this cultural stage women take thought to alter their persons, so as to conform more nearly to the requirements of the instructed taste of the time; and under the guidance of the canon of pecuniary decency, the men find the resulting artificially induced pathological features attractive. So, for instance, the constricted waist which has had so wide and persistent a vogue in the communities of the Western culture, and so also the deformed foot of the Chinese. Both of these are mutilations of unquestioned repulsiveness to the untrained sense. It requires habituation to become reconciled to them. Yet there is no room to question their attractiveness to men into whose scheme of life they fit as honorific items sanctioned by the requirements of pecuniary reputability. They are items of pecuniary and cultural beauty which have come to do duty as elements of the ideal of womanliness (Veblen, 1899, pp. 148-149).

Therefore, foot-binding may be seen as one of the more deleterious societal traits of China's ancient régime, so to speak. But unlike spirit-money, it has vanished. And with money, on the other hand, it is somewhat a different story.

\section{The "Death of Money": On Debt, Perishability, and the Beckoning of the "Spirit"}

In their economic interpretation of the custom, anthropologists have prevalently cited the work of Marx -two aspects thereof, in particular: his distinction "between the circulation of money as capital and its circulation as mere money," and the idea that money is a fetish hiding the fact that "money making more money" is an illusion.

Under the first contention, which distinguishes "money as money" from "money as capital," it has been argued that "money as money" is the business of humans, whereas "money as capital" is the (extortionary) affair of the gods. In other words, simple cash circulating in the hands of simple folk is simply purchase money with which humans buy "essential commodities"-including "a human body and a life-fate," to reconnect the argument with the earlier advertence to the commercial eschatology underlying the custom. Purchase money - consisting traditionally of paper bills - is the masses' money, which they use for their "petty needs" in this world, and, symbolically, in the next. Gods, by contrast, appear to be the superstitious projection of bankers-usurers. Gods, like moneyed capitalists, "lay out money as interest-bearing capital, with an expectation of receiving more than 
they originally lent: a series of offerings over the life-time of the individual in the course of normal religious activity."

During life, one should strive to reduce the debt through the performance of virtuous acts, through prayers, and, very important, through donations of money to the gods, both as burned spirit money and as real cash gifts to the temples (Gates, 1987, pp. 267, 269, 272-273).

According to this view, the custom, as we have noted above, comes across as a theatrical sublimation by poor people - peasants - of their being exploited at the hands of a "baronial" class of imperial commissars via the use of money, which, at heart, is construed as nothing but as an institutional subterfuge for robbing them of their "surplus labour" (Blake, 2011a, p. 108), and which they (the peasants) therefore burn in the course of a ceremonial thus possessed of a dual (semi-conscious) valence: as bribe-money to Hell, the mock-money burned is a dramatised offering representing the peasants' economic subjection, and as a "wire transfer" to their dead, it stands as an emulative practice patterned after the usages of that self-same leisure, the credentialed class whose predaciousness they putatively lament in the fumes of the torching.

\section{Interest, Gold, Scarcity}

The only certainty that emerges from the practice of burning netherworld banknotes is that, traditionally, "the great mass of the Chinese people [have been] in a chronic state of debt." And as debtors - like the vast majority of all men and women, in fact (the Chinese are no different from other peoples in this respect)-, the Chinese "[have been] daily concerned with the most practical question: how they shall pay interest to the minority who have lent the money" (Freedman, 1959).

Such is the primary institutional (and monetary) reality: the anchoring of the entire economic cycle to the foundational act of exploitation, which is the extension of money as a loan (i.e., debt), at interest. Historically, this is the institutional outcome of a near-universal cornering by a single industry - banking - of the precious metals, which are infelicitously recognised as society's conventional means of payment. This intuition belongs to Silvio Gesell (1864-1930), a Belle Époque businessman turned reformer, whose visionary blueprint for economic rebirth briefly attempted to come to practical life in the second, anarchist makeover of Bavaria's "Council Republic," during the of the pandemonium of WWI's aftermath (see, Preparata, 2005, pp. 48-56).

Considering the question in these terms, the worker, then, is not deceitfully defrauded of his "Plus-value" through legerdemain, i.e., through the monetary "illusion" of "money begetting more money." To contend this is to imply that one knows what the "intrinsic value" of labour's product is. But the economy does not reckon in terms of "value," but of price alone, for that is the only indicator that is actually-known to all parties involved. Incidentally, Eugène Ionesco's spins the matter semi-facetiously in his 1951 radiophonic sketch, Le salon de l'automobile ("At the Car Dealership"):

LE MONSIEUR: Oh! quelle belle voiture! [...] Elle vaut combien?

LE VENDEUR: Ça dépend du prix. ${ }^{3}$ (Ionesco, 1991, p. 1151)

The worker is robbed of his due because the employer deducts from it all the overhead, which, in turn, is derived from, or rather, imposed by the fundamental iniquity residing in the exaction of interest itself - exaction which "contaminates," so to speak, the entire chain of production and exchange.

The employer does not buy work, or working hours, or power of work, for he does not sell the power of work. What he buys and sells is the product of labour, and the price he pays is determined, not by the cost of breeding, training, and feeding a worker and his offspring (the physical appearance of the workers is only too good a proof that the employer cares little for all this), but simply by the price the consumer pays for the product. From this price the employer deducts the interest on his factory, the cost of raw material, including interest, and wages for his own work. The interest always corresponds to basic interest: the employer's wage, like all wages, follows the laws of competition: and the employer treats the raw material he intends his workmen to manufacture as every shop-keeper treats his merchandise. The employer lends the workmen machinery and raw material and deducts from the workers' produce the interest with which the raw material and machinery are burdened. The

\footnotetext{
${ }^{3}$ The Gentleman: Oh! What a beautiful car! [...] How much is it worth? The Car Sales man: It depends on the price.
} 
remainder, so-called wages, is in reality the price of the product delivered by the workmen. Factories are simply, therefore, pawnshops (Gesell, 1920, pp. 258-259, emphasis added).

In this portrayal, the factory itself is capable of generating interest ("profit") insofar as the total number of factories is scarce (and wage-labour is abundant). Machinery is scarce, and so are raw materials. And, again, the determining factor along this chain of subsequent constraints is the original exaction of basic interest (Preparata \& Elliott, 2004). The "faculty" of charging interest originates in the material property of money itself and, relatedly, in the power issuing from the commercial network of banking transactions, which have sprouted from the exaction of interest itself.

The power, the "numinosity" of money, which allows its proprietor to demand a price for its use - so-called "interest"-emanates from its imperishability when it traditionally assumes the form of gold. Thereafter, institutionally speaking, it has always been banking's chief preoccupation to transfer the "numinosity" of gold to its "paper" (the "acceptances" of yore, checks, and conventional "reserve notes"), which the population comes to accept in lieu of gold (for the latter is cumbersome). In this sense, the distinction, in terms of class, between "money as money" (for the people) and "money as capital" (for the upper crust, worldly and otherworldly) is, at first blush, not so much spurious as it is misleading. Money never circulates freely; it is always lent at interest, and that is how it is put into circulation: via a loan demanding a ceaseless chain of rental payments.

So, there is no illusion or "fetish" at play here: the charging of interest is a solid, unjust, and harsh reality, which, indisputably, colours the entire devotional texture of the money-burning custom. Indeed, one may say that the larcenous corruptness of the banking-bureaucratic elite is doubly "condemned" or "resented" in the practice of moneyburning by way of the provision of bribe-tokens on the one hand and of the whole repayment plan following the acquisition of a body and a fate in the supernatural realm, on the other. Money as we know it - i.e., as an imperishable commodified symbol - is "capital" by definition: again, it is never extended gratis.

And this explains why devotees, as a rule, are reluctant to burn real money: because it is (artificially) scarce and, therefore, expensive, they cannot afford to burn cash out of circulation. It is only insofar as real cash may be hoarded and consequently used to feed the so-called "informal" economy ("under the table," so to speak) that one may say that "purchase money" is the affair of simple people. Monetarily speaking, it is otherwise cogent to keep the cash circulating in the economy, even if that entails conveying it to a private and wasteful industry such as that of the token-makers, rather than senselessly annihilating what is de facto an essential commodity, which, because the banking cartel owns it, costs the productive economy resources for its injection. Hence the symbolic and ceremonial conversion of real cash into tokens in preparation for the burning liturgy.

\section{The ages of money}

But there is more. There is, indeed, something of a deeper nature behind the intuitive distinction between "purchase money" and "capital." For it is indeed the case that we see money circulating initially as "purchasing symbols" on their way to acquiring goods for immediate consumption (in the stores, the market). And it is no less true that, whatever is laid aside, in excess of what is needed for immediate consumption, we construe as savings, "saved money," or "capital." Technically, the latter is still money chasing (perishable) goods, but it is goods that are consumed in order to produce another sort of goods - items whose consumption will happen in the future, i.e.: "instrumental good," "investment goods," we call them.

All of which is to intimate that money, being at first remove the immediate reflection of economic activity, has a life span of its own. At the origin, when it is linked to the earth (agriculture), money is purchase money; goods (nutrients) are produced and consumed instantaneously, and the cycle repeats itself identically. When the goods of the earth are subsequently conveyed toward an artisanal (i.e., industrial) venture, they abandon the sphere of a subsistence economy and become "engaged"; the money representing them has been "saved." Saving is still a form of consumption: $a$ deferred consumption of durables.

And, then, there is a third, no less important and significant, stage.

Finally, when all this aging money, staggered by the various enterprises in which it was engaged, flows in ever-swelling rivulets to the communi- 
ty's saving accounts, much of it, as we said, is the specular expression of excess; therefore, it may be willingly given away. Moribund money is gift-money. Who shall receive it? In a purely economic sense, its legitimate recipients are those segments of the community not directly involved in productive work: state officialdom (bureaucrats and soldiers) and the spiritual sector (teachers, healers, and priests). In sum, the youth of money is the beginning of agriculture, its maturity is industrial expansion, and its death is spiritual emancipation (growth of the arts and sciences) (Preparata, 2006, p. 19).

As stated in the Introduction, we do not see it, but money conceals an age, the very age of the goods it is designed to accompany, in fact. And like these goods, which are born and eventually die, it must be that money itself must die. And it does though, again, we do not see it; or, are not allowed to see it, because, by law and (an iniquitous) institutional convention, money has been "decreed," and thereby is socially construed, as (an) imperishable (medium of exchange). This crucial observation lies at the heart of the nature of money and the reformist, sociological, and political debate that gravitates around it, the narrative and details that need not detain us here. Suffice it to say, then - and this is the beating heart of the reformist agenda issuing from such approach to the monetary question-, that for innovators like Gesell and Austrian theosophist Rudolf Steiner (1861-1925), who coined the metaphor of the "Ages of Money," there was only one way out of this societal impasse. The only expedient for melting away the deception by which the public is "sold" in the form of proprietary and imperishable "commodified means of payment" what ought to be, instead, a public, and thus free and incorporeal symbol is to make money die, by giving it an age. This translated into (periodically) "taxing money" (by affixing stamps on it: so-called "stamp scrip") or issuing time-dated certificates. For what it is and what it is supposed to effect, money was never meant to "keep": it ought to wither, die. And be reborn (i.e., rei-issued), along with everything else that composes the cycle.

Such a monetary schema perfectly accounts for the Chinese custom of money-burning: "spirit money," ghost-bills and the like are, properly speaking, gift-money: i.e., cash offerings, whose "conversion" into tokens punctually signals their nearing death. And, indeed, they are given away - to the dead. The practice itself - past the dramatisation, which, de facto, occults very little - actually makes this passage most manifest and explicit: the money is destroyed by being burned in effigy. There is no losing oneself in fakes and simulacra in this instance; there is no simulation afoot here. If anything, what money-burning effects is rather a counter-simulation: it is a liturgical démenti of the official monetary "discourse"; it is a semi-overt vindication of the underlying reality of money's age, ageing, and dying - a truth which the conventional and exploitative system has willingly effaced.

The practice is revelatory in that it unfolds to unmask the aboriginal simulation, i.e., the foundational deceit that conventionally congeals money in the collective perception as an imperishable means of payment. It is as if, demanding to be converted into "sacrificial" banknotes of the Underworld (so there is in this a touch of Bataillean truculence, after all...), the cash in people's wallets conveys that it has had an age all along and that it is now approaching death. And, as Steiner understood, the gifting most often marks rites by which the living commune with the spiritual realm. The priestly caste, which is deputised to manage the traffic with the Hereafter, is by definition a "kept class"; it is fed by the gift. Not by accident did the drachma bear the effigy of Athena; not by accident were coins in ancient Greece minted in the temple, and, to shift gears, not by accident does pop culture speak of bankers as "high priests." And so on.

Not by accident are the Chinese interacting with their dead when they burn ghost money (which, verily, they bought with "dying cash"). And it is now clear what the woman mentioned in the opening citation of this essay meant when she averred (in Sibylline fashion) that "burning [ghost money] is the proper way of storing its value": she meant that money, by its nature, can never keep; and that to manage it in the right fashion, one eventually ought to destroy it, and that is most appropriately done in conjunction with a deeply felt religious sentiment. It is a profound truth. The custom is thus perfectly congruent with the monetary and spiritual logic of the economic cycle, whatever opinion one may entertain as to the nature of the credence itself.

\section{Religion vs. Devoutness?}

There finally remains to assess whether this peculiar gifting is, per se, economically virtuous; in 
other words, whether the monetary repercussions of the interaction with the Underworld by way of one's ancestors are of any material benefit to the collectivity at large, especially in the way of charitable redistribution/succour (via the temples).

A sidenote on food offerings, first: one may remark that the food that is publicly laid out on tables, along with incense and spirit money, does not call for ritual altruism. It is eventually consumed by the donors themselves. And the suggestive banquet for the outcasts described earlier appears to have been some kind of vestigial ritual, which has now entirely disappeared.

Money. With Veblen, we have acknowledged that, so long as the cash flows to a private, pettysumptuary industry of scrip-manufacturers, the custom is not likely to transcend the enclave of "conspicuous waste." As said, some temples possess affiliated stores selling underworld money, but the bulk of the expense in this sector goes to private stores (and note-makers). So, considering that it is 1) polluting and, per se, 2) not conducive to any substantial charitableness, one could preliminarily conclude that, congruent as it may be with the imbricated structures of pecuniary flow, folklore, and devout belief, money-burning is of exiguous economic value to the welfare of the community.

Not without humour, the charge of animism could even be levelled on the doctrinal grounds by representing to money-burners how in the religious terms of the Gospel's metaphor (Matthew 6:20)-according to which a treasure spontaneously accrues in Heaven through good deeds - their practice amounts to a morally disengaged way of hyper-inflating such a pre-accumulated trove into nothingness (Blake, 2011b, p. 462). (Of course, the sarcasm fails to address the fact that remittances of ghost-money are chiefly addressed to "Hell," rather than Heaven). Orthodox Buddhism likewise berates the custom as a "low-class superstition" and deplores it especially in the guise of "rebirth money." It is a type of netherworld note that was created by Buddhists who emigrated from China to Taiwan; it takes the form of small yellow paper sheets bearing, printed in red Sanskrit letter, the mantra of rebirth recited for ghosts. Sutras, admonish Buddhist sages, should not be burnt (Yen, 2007, p. 75).

To view the torching of ghost money, economically speaking, as unqualifiedly animistic would be warranted if the custom were systematically unaccompanied by gratuitous acts of charitable donation, which, however, is manifestly not the case. For one, the incineration itself, the expense for which verily absorbs but a diminutive amount of cash (the standard package of ghost money + incense retails for 100 NT\$, ca. 3 US\$), is customarily coupled with offertories to the temples of substantially higher amounts. (I have been told that within the precincts of the private temple, things are handled "like in a clinic": Shamans suggest to the devotees the proper amounts to burn in accordance with the particular "problems" these wish to address. The spirit-money is bought on the temples' premises). And second, as we set down earlier, the doctrine associated with the (commercial) eschatology of the custom prescribes the commission of "virtuous acts indeed, through prayers, and, very important, through donations of money to the gods, both as burned spirit money and as real cash gifts to the temples" (Veblen, 1899, pp. 148-149).

To conclude with a marginal annotation, it appears that, in its essentials, the custom possesses more than enough popular traction and sufficient economic "virtue" to perpetuate itself in the twenty-first century and beyond. Neither the issuance of a new digital currency by the central bank of the People's Republic of China (China, 2017) nor the development of cryptocurrencies alternative networks (Casey \& Vigna, 2015), which is nowadays cutting-edge business in China, represents an ostensible obstacle for the ritual practice of moneyburning. So long as any of these new artificially scarce, man-made, commodified currencies ("Bitcoin," the standard-bearer of crypto-money is also known as "digital gold") may be spent at the local convenience stores, or even at temples (Churches in Sweden, e.g., have already enabled their faithful to make oblations by swiping their cards over digitised charity-boxes), their owners can keep the custom alive and thus be at liberty to send up in flames as much spirit money as they see fit. It could be so, unless, of course, the current build-up for environmental regulation should become such as prohibiting the custom altogether. It is thereafter a matter of pure speculation whether, in order to salvage tradition, one could devise, in line with the aforementioned digital developments and the new hyper-modern varieties of netherworld bills, an online system for the digitised incineration of crypto-ghost-notes. 


\section{REFERENCES}

1. Bataille Georges. La part maudite, précédée de la notion de dépense. Paris: Les Éditions de minuit; 1967 [1949].

2. Blake C. Fred. Burning Money. The Material Spirit of Chinese Lifeworld. Honolulu: University of Hawaii Press; 2011a.

3. Blake C. Fred. Lampooning the Paper-Money Custom in Contemporary China. Journal of Asian Studies. 2011b;70(2, May):449-459.

4. Casey Michael J., Vigna Paul. The Age of Cryptocurrency: How Bitcoin and Digital Money Are Challenging the Global Economic Order. New York: Random House; 2015.

5. China is Developing its Own Digital Currency. Bloomberg. April 2017 https://www.bloomberg.com/news/ articles/2017-02-23/pboc-is-going-digital-as-mobile-payments-boom-transforms-economy

6. Freedman Maurice. The Handling of Money: A Note on the Background to the Economic Sophistication of Overseas Chinese. Man. 1959, April; (88, 89):64-65.

7. Gates Hill. Money for the Gods. Modern China. 1987;13(3, July):259-277.

8. Gesell Silvio. The Natural Economic Order. San Antonio, Texas: Free Economy Publishing. 1920 [1916].

9. Hou Ching-Lang. Les papiers monnaies d'offrande dans la religion chinoise. Annuaires de l'École pratique des hautes études. 1971;80-81:116-121.

10. Ionesco Eugène. Théâtre complet. (Paris: Gallimard, La Bibliothèque de la Pleïade; 1991.

11. Pound Ezra. The Cantos of Ezra Pound. New York: New Directions; 1996 [1915-1962].

12. Pound Ezra. Selected Prose, 1909-1965. New York: Faber and Faber; 1978.

13. Preparata Guido G. The Ideology of Tyranny. The Use of Neo-Gnostic Myth in American Politics. New York: Macmillan; 2011.

14. Preparata Guido G. Un(for)giving: Bataille, Derrida, and the Postmodern Denial of the Gift. Catholic Social Science Review. 2008;(13):169-200.

15. Preparata Guido G. Perishable Money in a Threefold Commonwealth: Rudolf Steiner and the Social Economics of an Anarchist Utopia. Review of Radical Political Economics. 2006(Winter);38(4):619-648.

16. Preparata Guido. G. Conjuring Hitler. How Britain and America Made the Third Reich. London: Pluto Press; 2005.

17. Preparata Guido G., Elliott John E. Free-Economics: The Vision of Reformer Silvio Gesell. International Journal of Social Economics. 2004;31(10):923-954.

18. Rogoff Kenneth S. The Curse of Cash. Princeton and Oxford: Princeton University Press; 2016.

19. Seidel Anna. Token of Immortality in Han Graves. Numen. 1982(July); XXIX(1):110-111.

20. Tarde Gabriel. Fragment d'histoire future. Paris: Éditions Glyphe. 2015 [1896].

21. Veblen Thorstein. The Engineers and the Price System. New York: Huebsch; 1921.

22. Veblen Thorstein. The Theory of Business Enterprise. New York: Macmillan; 1904.

23. Veblen Thorstein. The Theory of the Leisure Class. And Economic Study of Institutions. New York: Macmillan; 1899.

24. Wolf Arthur P. Gods, Ghosts, and Ancestors. In Arthur P. Wolf (Ed.), Religion and Ritual in Chinese Society (Chapter 7). Stanford: Stanford University Press; 1974.

25. Yen Sheng. Orthodox Chinese Buddhism. A Contemporary Chan Master's Answers to Common Questions. Berkeley, California: North Atlantic Books; 2007.

\section{ABOUT THE AUTHOR}

Guido Giacomo Preparata - D.Sc. in Political Economy, MPhil in Criminology, Senior Lecturer in Political Economy and Social Sciences at the Pontifical Gregorian University in Rome, Italy

ggprep@yahoo.com

\section{ОБ АВTOPE}

Гвидо Джакомо Препарата - доктор политических наук, магистр криминологии, старший преподаватель политической экономии и социальных наук Папского Григорианского университета в Риме, Италия. ggprep@yahoo.com 